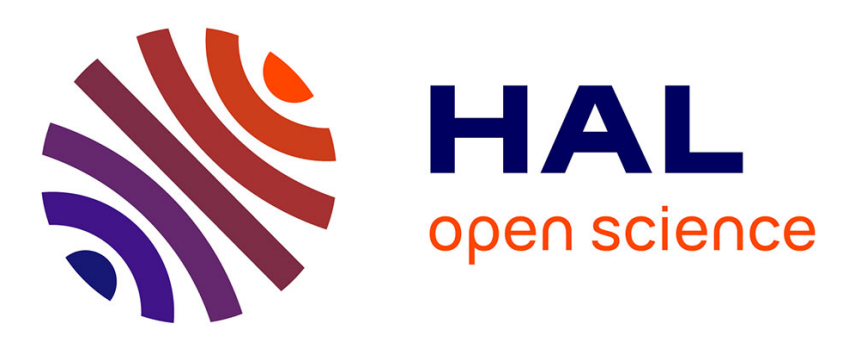

\title{
Soil factors associated with infection by Collybia fusipes and decline of oaks
}

\author{
C. Camy, D de Villebonne, C. Delatour, Benoit Marçais
}

\section{To cite this version:}

C. Camy, D de Villebonne, C. Delatour, Benoit Marçais. Soil factors associated with infection by Collybia fusipes and decline of oaks. Forest Pathology, 2003, 33 (4), pp.253-266. 10.1046/j.14390329.2003.00333.x . hal-02089796

\section{HAL Id: hal-02089796 https://hal.science/hal-02089796}

Submitted on 4 Apr 2019

HAL is a multi-disciplinary open access archive for the deposit and dissemination of scientific research documents, whether they are published or not. The documents may come from teaching and research institutions in France or abroad, or from public or private research centers.
L'archive ouverte pluridisciplinaire HAL, est destinée au dépôt et à la diffusion de documents scientifiques de niveau recherche, publiés ou non, émanant des établissements d'enseignement et de recherche français ou étrangers, des laboratoires publics ou privés. 


\title{
Soil factors associated with infection by Collybia fusipes and decline of oaks
}

\author{
By C. CAmy ${ }^{1}$, D. de Villebonne ${ }^{2}$, C. Delatour ${ }^{1}$ and B. MarÇais ${ }^{1}$ \\ ${ }^{1}$ Unité de Pathologie Forestière, INRA, Centre de Nancy, F54280, Champenoux, France (Phone: +33-3-83-39- \\ 41-33, Fax: +33-3-83-39-40-69, E-mail: marcais@nancy.inra.fr) \\ 2 Département de la Santé des Forêts, DERF, 93 rue de Curembourg, F45404, Fleury les Aubrais, France
}

\section{Summary}

Collybia fusipes is the cause of a root rot of oaks in Europe. Infection by the pathogen is site dependent and inconsistently correlated with crown deterioration. This study aimed at clarifying the relationship between soil factors and $C$. fusipes impact on tree health. The database of the Département de la Santé des Forêts, the forest health survey service, collected over the French forest during the last 12 years allowed us to perform a large scale study dealing with soil textures in which C. fusipes was reported to induce problems on Quercus robur and/or Q. petraea. Furthermore, a specific survey from 30 plots in north eastern France was carried out to determine which of the soil factors, such as texture, degree of waterlogging, presence and nature of a layer limiting rooting, carbon/nitrogen ratio, cation exchange capacity, or $\mathrm{pH}$ could be related to an increased risk of decline of pedunculate oaks infected by $C$. fusipes. The main results were that $C$. fusipes is preferentially distributed on coarse textured soils and that its impact on tree crown appearance also increased with the soil sand content.

\section{Introduction}

Collybia fusipes (Bull.:Fr) Quél. is the cause of an oak root rot in Europe. This fungus has been first mentioned in association with the decline of pedunculate oak in 1983 (Delatour and GUILLAUMIN 1984, GUILLAUMIN et al. 1985). C. fusipes is widespread throughout the French oak forests (MARÇAIS et al. 1998-a, PIOU et al. 2002). Its basidiomes are frequent from spring to autumn, occurring in clumps at the base of living trees. The basidiome clumps are connected to infected roots through a perennial organ, the pseudorhiza (BULLER 1958). Based on field surveys, MARÇAIS et al. (2000) and PIOU et al. (2002) have shown that $C$. fusipes basidiomes are good indicators of root infection. A research program was initiated 10 years ago to determine the role of this pathogen in the oak decline syndromes and to find in which type of site it could be an important factor involved in the decline process.

C. fusipes is a slow primary parasite able to induce typical orange lesions located on large roots and root collar. It can induce a drastic destruction of the root system (MARÇAIS and DELATOUR 1996, MARÇAIS et al. 1999). Disease frequency is higher in pedunculate (Quercus robur L.) and red oak stands (Q. rubra L.) as compared to the sessile oak ones (Q. petraea Liebl.) (MARÇAIS et al. 1998-a, PIOU et al. 2002), reflecting different susceptibility of these three oak species to the parasite (MARÇAIS and CAËL 2000). Field observations also showed that this parasite has a higher incidence in coarse textured soils (unpublished data). A field study carried out in five oak stands, evidenced that severe $C$. fusipes root infection could not always be correlated with deterioration of oak crown. The causes of this inconsistent relationship between infection of the oak and their decline still remained unclear, although it appeared that it could be related with coarseness of the soil texture, and possibly to the water holding capacity of the soil (MARÇAIS et al. 2000). However, although severe root infections induced by $C$. fusipes were not always associated with a deterioration of the tree 
crown, they were associated with a reduction in tree growth in all the stands studied (MARÇAIS and CAËL 2001). Soil conditions, in particular soils with coarse texture have been mentioned to be related with increasing impact and incidence of root rot diseases, such as those induced by Armillaria ostoyae (MALLETT and MAYNARD 1998, Whitney 1984, WIENSCYK et al. 1997) or Heterobasidion annosum (ALEXANDER et al. 1975, BAKER et al. 1993, FROELICH et al. 1966).

This study aimed at clarifying which soil conditions promote $C$. fusipes incidence in oak stands. At first, the relationship between soil texture, decline of oaks and $C$. fusipes was studied at a large scale using data collected during the last 12 years by the Département de la Santé des Forêts (DSF), the French forest health survey service. Thereafter, a specific survey was carried out in north eastern France to determine which soil factors could be related with an increased risk in the decline of pedunculate oaks infected with $C$. fusipes.

\section{Materials and methods}

\subsection{Analysis of the database of the French forest health survey service (DSF)}

\subsubsection{Information available in the DSF database}

The database of the DSF was used to study in which type of site $C$. fusipes root rot was reported to cause problems in France on $Q$. robur and/or Q. petraea. This database, created in 1989, is a compilation of reports made by a network of foresters who are trained to diagnose all types of forest health problems i.e. abiotic, entomological or pathological. Health problems of $Q$. robur and/or Q. petraea were reported 10000 times between 1989 and 2001, with 161 reports involving $C$. fusipes root rot. The majority of reports in the database refers to defoliation by insects $(61 \%)$, powdery mildew $(8 \%)$, decline $(8.5 \%)$ and frost damages $(5 \%)$. Site characteristics used in this study were stand age, soil texture, degree of soil waterlogging and the dominant oak species. Soil textures were reported as clay, loam or sand as dominant and secondary textures. They were grouped in the following categories according to the overall frequency: (1) clay as dominant and clay or loam as secondary textures, (2) loam as dominant and clay as secondary texture, (3) loam as both dominant and secondary texture, (4) loam as dominant and sand as secondary texture and (5) sand as dominant and loam or sand as secondary textures. Waterlogging was reported as severe or non severe logging. Not all reports contained the necessary information, so only those including this information were considered in the analysis.

\subsubsection{Database investigations}

As C. fusipes is known to be mainly a problem of mature trees (MARÇAIS et al. 1998-a) and as no mention of the pathogen was made in young stands, only reports referring to mature stands, or to stands older than 80 years, or higher than $15 \mathrm{~m}$ where taken into account. Care was also taken to consider stands only once when problems were reported in the same stand over several years.

In the DSF database, the characteristics of the stands where $C$. fusipes was reported were first compared to those of stands where health problems other than $C$. fusipes were reported (respectively 119 and 2402 stands). This was done using chi-square tests.

The distribution of soil textures in stands where $C$. fusipes is mentioned in the DSF database was also compared with the one observed in the 154 Q. robur/ Q. petraea stands of the French part of the European forest health monitoring network (ICP-Forests, International Co-operative Programme on Assessment and Monitoring of Effects of Air pollution on Forest), hereafter called 'European network'. This network is established in a systematic way, on a $16 \mathrm{~km} \times 16 \mathrm{~km}$ grid and was used to establish the reference distribution of soil texture over the French oak forest. Because the trained foresters of the DSF are very 
unevenly distributed throughout the whole territory, it induces a bias in the distribution of the $C$. fusipes reports which differs significantly from the oak stand distribution observed in the

Table1. Description of plot characteristics of the plot survey

\begin{tabular}{|c|c|c|c|c|c|c|c|}
\hline Plot & Region & $\begin{array}{l}\text { Number of oaks } \\
(\%) \text { infected }\end{array}$ & Stand & $\begin{array}{c}\text { Soil layer } \\
\text { limiting rooting }\end{array}$ & \%sand & $\mathrm{pH}$ & $\begin{array}{l}\text { Quercus } \\
\text { species }\end{array}$ \\
\hline Adelans & Haute-Saône & $41(27)$ & $\begin{array}{l}\text { Old coppice with beech } \\
\text { and oak standards }\end{array}$ & $\begin{array}{l}\text { None until } \\
120 \mathrm{~cm}\end{array}$ & 7.8 & 4.8 & Q. robur \\
\hline Ainvelle 1 & Haute-Saône & $38(32)$ & $\begin{array}{l}\text { Old coppice with oak } \\
\text { standards }\end{array}$ & $\begin{array}{l}\text { None until } \\
120 \mathrm{~cm}\end{array}$ & 17.8 & 4.5 & Q. robur \\
\hline Ainvelle 2 & Haute-Saône & $42(36)$ & $\begin{array}{l}\text { Old coppice with oak } \\
\text { standards }\end{array}$ & $\begin{array}{c}\text { Gravel layer } \\
80 \mathrm{~cm}\end{array}$ & 47.2 & 4.1 & Q. robur \\
\hline Ainvelle 3 & Haute-Saône & $40(38)$ & $\begin{array}{l}\text { Old coppice with oak } \\
\text { standards }\end{array}$ & $\begin{array}{l}\text { None until } \\
120 \mathrm{~cm}\end{array}$ & 65.2 & 4.3 & Q. robur \\
\hline Amance & $\begin{array}{l}\text { Meurthe-et- } \\
\text { Moselle }\end{array}$ & $34(32)$ & $\begin{array}{l}\text { Old coppice with oak } \\
\text { standards }\end{array}$ & $\begin{array}{c}\text { Clayey hardpan } \\
70 \mathrm{~cm}\end{array}$ & 10.5 & 5.7 & Q. robur \\
\hline Saint Aubin 1 & Jura & $40(38)$ & $\begin{array}{l}\text { Old coppice with oak } \\
\text { standards }\end{array}$ & $\begin{array}{l}\text { Fragipan } \\
50 \mathrm{~cm}\end{array}$ & 9.5 & 4.8 & Q. robur \\
\hline Saint Aubin 2 & Jura & $38(42)$ & $\begin{array}{l}\text { Old coppice with oak } \\
\text { standards }\end{array}$ & $\begin{array}{l}\text { Fragipan } \\
50 \mathrm{~cm}\end{array}$ & 9.5 & 4.8 & Q. robur \\
\hline Les Aynans 7 & Haute-Saône & $33(45)$ & $\begin{array}{l}\text { Old coppice with oak } \\
\text { standards }\end{array}$ & $\begin{array}{c}\text { Clayey hardpan } \\
70 \mathrm{~cm}\end{array}$ & 20.1 & 4.2 & Q. robur \\
\hline Les Aynans 28 & Haute-Saône & $39(33)$ & $\begin{array}{l}\text { Coppice with oak } \\
\text { standards }\end{array}$ & $\begin{array}{c}\text { Gravel layer } \\
70 \mathrm{~cm}\end{array}$ & 57.5 & 4.1 & Q. robur \\
\hline Les Aynans 35 & Haute-Saône & $42(40)$ & $\begin{array}{l}\text { Old coppice with oak } \\
\text { standards }\end{array}$ & $\begin{array}{c}\text { Gravel layer } \\
80 \mathrm{~cm}\end{array}$ & 56.2 & 4.5 & $\begin{array}{l}\text { Q. robur + } \\
\text { Q. petraea }\end{array}$ \\
\hline Champagney & Haute-Saône & $39(28)$ & $\begin{array}{l}\text { Beech and oak } \\
\text { standards }\end{array}$ & $\begin{array}{l}\text { None until } \\
120 \mathrm{~cm}\end{array}$ & 46.4 & 4.2 & Q. robur \\
\hline Champenoux & $\begin{array}{l}\text { Meurthe-et- } \\
\text { Moselle }\end{array}$ & $40(33)$ & $\begin{array}{l}\text { Old coppice with oak } \\
\text { standards }\end{array}$ & $\begin{array}{c}\text { Clayey hardpan } \\
60 \mathrm{~cm}\end{array}$ & 8.7 & 5 & Q. robur \\
\hline Equevilley & Haute-Saône & $42(38)$ & $\begin{array}{l}\text { Old coppice with beech } \\
\text { and oak standards }\end{array}$ & $\begin{array}{l}\text { None until } \\
120 \mathrm{~cm}\end{array}$ & 40.6 & 4.5 & Q. robur \\
\hline Filain & Haute-Saône & $50(8)$ & High forest of oaks & $\begin{array}{c}\text { Clayey hardpan } \\
75 \mathrm{~cm}\end{array}$ & 3.6 & 5.8 & $\begin{array}{l}\text { Q. robur+ } \\
\text { Q. petraea }\end{array}$ \\
\hline Gouhenans & Haute-Saône & $32(31)$ & $\begin{array}{l}\text { Old coppice with beech } \\
\text { and oak standards }\end{array}$ & $\begin{array}{l}\text { None until } \\
120 \mathrm{~cm}\end{array}$ & 8.1 & 4.7 & Q. robur \\
\hline Gremecey & $\begin{array}{l}\text { Meurthe-et- } \\
\text { Moselle }\end{array}$ & $38(39)$ & $\begin{array}{l}\text { Old coppice with oak } \\
\text { standards }\end{array}$ & $\begin{array}{c}\text { Clayey hardpan } \\
50 \mathrm{~cm}\end{array}$ & 2.3 & 4.4 & $\begin{array}{l}\text { Q. robur }+ \\
\text { Q. petraea }\end{array}$ \\
\hline Hautevelle & Haute-Saône & $42(33)$ & $\begin{array}{l}\text { Old coppice with beech } \\
\text { and oak standards }\end{array}$ & $\begin{array}{c}\text { Clayey hardpan } \\
80 \mathrm{~cm}\end{array}$ & 17.3 & 5.3 & $\begin{array}{l}\text { Q. robur+ } \\
\text { Q. petraea }\end{array}$ \\
\hline Saint Hilaire & Doubs & $28(50)$ & $\begin{array}{l}\text { Old coppice with beech } \\
\text { and oak standards }\end{array}$ & $\begin{array}{l}\text { Fragipan } \\
80 \mathrm{~cm}\end{array}$ & 11.2 & 4.9 & $\begin{array}{l}\text { Q. robur + } \\
\text { Q. petraea }\end{array}$ \\
\hline Lure & Haute-Saône & $38(47)$ & $\begin{array}{l}\text { Old coppice with beech } \\
\text { and oak standards }\end{array}$ & $\begin{array}{c}\text { Gravel layer } \\
60 \mathrm{~cm}\end{array}$ & 47.5 & 4.7 & Q. robur \\
\hline Mailleroncourt & Haute-Saône & $41(39)$ & $\begin{array}{l}\text { High forest of beech and } \\
\text { oaks }\end{array}$ & $\begin{array}{c}\text { Gravel layer } \\
70 \mathrm{~cm}\end{array}$ & 8.6 & 4.8 & Q. robur \\
\hline Mersuay 36 & Haute-Saône & $41(44)$ & $\begin{array}{l}\text { Old coppice with oak } \\
\text { standards }\end{array}$ & $\begin{array}{c}\text { Gravel layer } \\
70 \mathrm{~cm}\end{array}$ & 62.5 & 4.5 & Q. robur \\
\hline Mersuay 5 & Haute-Saône & $50(22)$ & $\begin{array}{l}\text { Old coppice with oak } \\
\text { standards }\end{array}$ & $\begin{array}{c}\text { Gravel layer } \\
70 \mathrm{~cm}\end{array}$ & 26.7 & 5.2 & Q. robur \\
\hline Roye & Haute-Saône & $47(53)$ & $\begin{array}{l}\text { High forest of oaks and } \\
\text { beeches }\end{array}$ & $\begin{array}{l}\text { None until } \\
120 \mathrm{~cm}\end{array}$ & 16.1 & 4.5 & Q. robur \\
\hline La Tour de Sçay & Doubs & $35(31)$ & $\begin{array}{l}\text { Old coppice with beech } \\
\text { and oak standards }\end{array}$ & $\begin{array}{c}\text { Gravel layer } \\
90 \mathrm{~cm}\end{array}$ & 32.3 & 4.4 & $\begin{array}{l}\text { Q. petraea } \\
+ \text { Q. robur }\end{array}$ \\
\hline Vauvillers 1 & Haute-Saône & $39(26)$ & $\begin{array}{l}\text { Old coppice with beech } \\
\text { and oak standards }\end{array}$ & $\begin{array}{c}\text { Clayey hardpan } \\
70 \mathrm{~cm}\end{array}$ & 7.8 & 5.2 & Q. robur \\
\hline Vauvillers 2 & Haute-Saône & $40(33)$ & $\begin{array}{l}\text { Old coppice with beech } \\
\text { and oak standards }\end{array}$ & $\begin{array}{c}\text { Clayey hardpan } \\
70 \mathrm{~cm}\end{array}$ & 10.2 & 5 & Q. robur \\
\hline Villers Grélot & Doubs & $38(34)$ & $\begin{array}{l}\text { Old coppice with beech } \\
\text { and oak standards }\end{array}$ & $\begin{array}{l}\text { None until } \\
120 \mathrm{~cm}\end{array}$ & 3.7 & 4.8 & $\begin{array}{l}\text { Q. robur + } \\
\text { Q. petraea }\end{array}$ \\
\hline Villey St Etienne & $\begin{array}{l}\text { Meurthe-et- } \\
\text { Moselle }\end{array}$ & $51(41)$ & $\begin{array}{l}\text { Old coppice with oak } \\
\text { standards }\end{array}$ & $\begin{array}{c}\text { Gravel layer } \\
60 \mathrm{~cm}\end{array}$ & 68.4 & 4.3 & Q. robur \\
\hline Vitrimont & $\begin{array}{l}\text { Meurthe-et- } \\
\text { Moselle }\end{array}$ & $43(51)$ & $\begin{array}{l}\text { High forest of oaks and } \\
\text { beeches }\end{array}$ & $\begin{array}{c}\text { Gravel layer } \\
80 \mathrm{~cm}\end{array}$ & 64.2 & 4.1 & $\begin{array}{l}\text { Q. robur + } \\
\text { Q. petraea }\end{array}$ \\
\hline Vy les Lures & Haute-Saône & $41(44)$ & $\begin{array}{l}\text { Coppice with oak } \\
\text { standards }\end{array}$ & $\begin{array}{l}\text { Fragipan } \\
90 \mathrm{~cm}\end{array}$ & 10.7 & 5.4 & Q. robur \\
\hline
\end{tabular}

NOTE: the sand content was evaluated at $30 \mathrm{~cm}$ below the soil surface with the sulfochromic method. The $\mathrm{pH}$ at $10 \mathrm{~cm}$ below the soil surface was measured using $10 \mathrm{~g}$ of dry soil in $50 \mathrm{ml}$ of deionized water.

European network. To take this 'observer bias' into account, France was divided into five areas and a weight was attributed to DSF reports of each areas. This weight for each area was computed as $P A_{e n} / P A_{r-d s f}$, where $P A_{e n}$ is the proportion of the oak stands found in the European network for a specific area and $\mathrm{PA}_{\mathrm{r}-\mathrm{dst}}$ the proportion of DSF reports concerning 
Q. robur / Q. petraea for this area. This way a large weight was attributed to reports coming from areas with few reports compared to their importance in the french oak forest. The European network was used to generate a theoretical soil texture distribution in the oak forest and the distribution of $C$. fusipes reports in the soil texture categories was compared to it by chi-square tests, each reports being weight by $\mathrm{PA}_{\text {en }} / \mathrm{PA}_{\mathrm{r}-\mathrm{dsf}}$.

In the DSF database, the soil texture of stands where $C$. fusipes was associated with oak decline was also compared to soil texture of stands where $C$. fusipes was not associated with decline, using chi-square tests. A report of $C$. fusipes was considered to be associated with a decline problem whenever either a decline was explicitly reported, mortality or secondary organisms such as Agrilus sp. or Armillaria sp. were reported and when the report was stated to concern more than only isolated trees.

\subsection{Relationship between soil factors and decline risk of $C$. fusipes infected trees}

\subsubsection{Plot survey}

Thirty oak stands with at least $25 \%$ of the trees infected by $C$. fusipes were selected in north eastern France. Twelve of these plots were also reported in the DSF database. Half of the plots were pure stands of pedunculate oaks, while the other half were stands of pedunculate oaks mixed with sessile oaks or beech (Fagus sylvatica L.). Stands were all older than 90 years. Soil textures, $\mathrm{pH}$ and the vertical rooting limits were variable between plots (Table 1).

In each plot, a group of 28 to 51 contiguous pedunculate oaks located in an area of about $5000 \mathrm{~m}^{2}$ was selected (Table 1). All the pedunculate oaks present were selected, independently of their social status. The oak species was determined based on leaf morphology observed with binoculars. In mixed oak stands, sessile oaks were not included in the sample. During the period of basidiome production, presence/absence of $C$. fusipes infection was assessed for each tree. The root collar and the major roots were carefully inspected for presence of basidiomes or pseudorhiza. Pseudorhizae are persistent dark stroma-like fungal structures of $2-5 \mathrm{~cm}$ diameter that connect $C$. fusipes basidiome clusters with the root (BULLER 1958).

Crown health status was assessed for each tree. It was rated in two categories, i.e. heavily or not declining according to an adaptation of the rating system proposed by NAGELEISEN (1995): (0) crown healthy or moderately declining, with less than $50 \%$ defoliation; (1) crown severely declining, with large dead limbs in the upper part of the crown and/or loss of more than $50 \%$ of fine branches.

On each plot, a pit was dug near a tree located in the middle of the sampled oaks to observe soil characteristics. Soils were described specifically for the degree of waterlogging, i.e. depth at which appear the first signs of hydromorphia (reddish traces of insoluble oxidized iron deposition and / or discoloration indicating iron depletion) and for the presence and nature of a soil layer susceptible to limit vertical root growth. The vertical rooting limits were rated in 4 categories: absence of limits, presence of a gravel layer, a clayey hardpan or a fragipan (compacted silt). These soil parameters were also described at the base of two oaks located on opposite sides of the tree group by observation of a soil core extracted with an earth auger. The depth to waterlogging signs and to the layer limiting vertical root growth was taken into account as the mean of the three values observed in each group of trees. In each plot a sample of soil from a depth of $10 \mathrm{~cm}$ was analysed for carbon and organic matter (sulfochromic method), total nitrogen (Kjeldahl method), cation exchange capacity (cobaltihexamin method) and $\mathrm{pH}(10 \mathrm{~g}$ of dry soil in $50 \mathrm{ml}$ of deionized water). Another soil sample, from a depth of $30 \mathrm{~cm}$, was analysed in the laboratory for texture (\%sand). All these soil analyses were carried out following the AFNOR norms for soil quality assessment (AFNOR 1999). 


\subsubsection{Statistical analysis of the plot survey}

The likelihood of oak decline was analysed using logistic regression based on soil factors (sand content, depth at which appear the first waterlogging signs hereafter called waterlogging depth, soil $\mathrm{pH}$, presence and nature of a soil layer limiting rooting, carbon/nitrogen ratio or cation exchange capacity) and presence of signs of $C$. fusipes infection (binary variable) as independent variables (genmod procedure) (SAS 1989). At first, each soil factor was tested individually, together with the presence or absence of infection signs by $C$. fusipes and the interaction between the studied soil factor and the infection variable. The model used was:

$$
\log (p /(1-p))=\alpha+\beta \text { soil factor }+\gamma \text { infection }+\delta \text { (soil factor } x \text { infection) }
$$

where $p$ is the likelihood of a tree being declining, 'soil factor' is the soil characteristic studied and 'infection' is the presence or absence of infection signs by C. fusipes. A sequence of nested models were fitted, beginning with the simplest model with only the intercept term and continuing through models of increasing complexity i.e. type 1 analysis. Residual deviancies were computed for each successive model and the significance of the last introduced variable was assessed by computing the Pvalue of the deviance decrease associated with the introduction of the new variable (COLLETT, 1991). The model validity was checked using the deviance/degrees of freedom ratio, by plotting deviance residuals against the linear predictor and using a half-normal plot (COLLETT, 1991). Whenever a significant interaction 'soil factor $\mathrm{x}$ infection' was observed, i.e. whenever the impact of infection on tree decline status depended on the soil characteristic, the odds ratio $\exp ((\gamma+\delta \times$ soil factor $) \times$ infection) was computed with "infection" taking the value of 1 . This odds ratio is an estimate of the relative risk of decline for infected oaks, i.e. the increase in the likelihood of oaks showing signs of $C$. fusipes infection to be declining as compared to oaks without infection signs.

Then, the model (1) with the percent of sand content as a soil factor was compared with 2 more complex models: (i) the model (1) with waterlogging depth and the interaction infection $x$ waterlogging depth as additional variables; (ii) the model (1) with the surface soil $\mathrm{pH}$ and interaction infection $\mathrm{x}$ soil $\mathrm{pH}$ as additional variables. The collinearity between the soil factors was assessed by comparing the residual deviance of model (i) or (ii) with the one of model 1 and testing whether the introduction of additional variables in those 2 models was associated with a significant drop in deviance.

\section{Results}

\subsection{Analysis of the database of the French forest health survey service (DSF)}

In the DSF database, presence of $C$. fusipes was mainly reported in $Q$. robur stands (67\%) and to a lower extent in Q. petraea or mixed Q. robur/Q. petraea stands $(16-17 \%$ each). This distribution is significantly different from the one found for reports concerning health problems other than $C$. fusipes. Indeed, $C$. fusipes reports represent $8.5 \%$ of the overall reports for $Q$. robur, $3.9 \%$ for $Q$. petraea and $1.8 \%$ for mixed $Q$. robur/Q. petraea stands $\left(\chi^{2}=56.05, \mathrm{df}=2, \mathrm{p}<0.001\right)$. The difference is even greater if one consider the $C$. fusipes reports associated with decline: they represent $5.4 \%$ of the reports for $Q$. robur, $1.2 \%$ for $Q$. petraea and $0.9 \%$ for mixed $Q$. roburlQ. petraea stands. For the following analysis $C$. fusipes reports on $Q$. petraea and mixed $Q$. robur/Q. petraea were grouped together because of too low frequencies.

Only 87 reports $(3.5 \%)$ give information about the degree of waterlogging. So, the severity of waterlogging was not available for most of the reports. No significant relationship could be established between waterlogging and the incidence of $C$. fusipes, although $1.7 \%$ of the reports dealing with waterlogged soil were associated with the occurrence of $C$. fusipes and $3.6 \%$ with health problems other than $C$. fusipes (Fisher's exact test of $0.92, p=0.144$ ). 
For $Q$. robur, Table 2 shows that $C$. fusipes reports were distributed in categories of soil texture differently than the reports dealing with other kind of problems $\left(\chi^{2}=89.22\right.$, $\mathrm{df}=4$, $p<0.001$ ). This was due to the infrequent mention of $C$. fusipes in fine textured soils (clay to loamy clay) and its high frequency in coarse textured ones (loamy sand to sand). A similar tendency was observed for the distribution in the soil texture categories of $C$. fusipes reports on $Q$. robur as compared with that of $Q$. robur European network stands, although the difference was not significant $\left(\chi^{2}=7.61, \mathrm{df}=4, \mathrm{p}=0.107\right)$. By contrast, for $Q$. petraea and mix $Q$. robur/Q. petraea stands, no difference in frequency distribution in terms of soil texture was observed between DSF reports of $C$. fusipes problems or of other problems $\left(\chi^{2}=4.83\right.$, $\mathrm{df}=4, \mathrm{p}=0.305$, Table 2). The DSF reports of $C$. fusipes were more frequent than expected in fine textured soils as compared to oak stand frequency distribution in the European network (table 2, $\chi^{2}=16.02, \mathrm{df}=4, \mathrm{p}=0.003$ ).

Table 2. Soil texture distribution for the DSF reports on oak concerning $C$. fusipes or other health problems, as well as the soil texture distribution observed for the oak stands of the European network. Textures are given as dominant (C: clay, L: loam or S: sand) and secondary (c: clay, l: loam or s: sand).

\begin{tabular}{|c|c|c|c|c|c|c|c|}
\hline & \multirow{2}{*}{ Reports of : } & \multicolumn{5}{|c|}{ Soil texture } & \multirow{2}{*}{$\begin{array}{l}\text { Number of } \\
\text { stands. }\end{array}$} \\
\hline & & $\mathrm{C}$ to $\mathrm{Cl}$ & Lc & L & Ls & SI to $S$ & \\
\hline \multirow{3}{*}{ Q. robur } & C. fusipes (DSF) & $10.1 \%$ & $25.5 \%$ & $13.2 \%$ & $8.4 \%$ & $42.8 \%$ & 81 \\
\hline & $\begin{array}{l}\text { Other problems than } \\
\text { C. fusipes (DSF) }\end{array}$ & $34.0 \%$ & $29.2 \%$ & $15.4 \%$ & $12.6 \%$ & $8.8 \%$ & 879 \\
\hline & European Network & $10.4 \%$ & $33.3 \%$ & $16.7 \%$ & $10.4 \%$ & $29.2 \%$ & $48^{\mathrm{a}}$ \\
\hline \multirow{3}{*}{$\begin{array}{l}\text { Q. petraea and } \\
\text { mixed Q. robur } \\
\text { / Q. petraea }\end{array}$} & C. fusipes (DSF) & $48.4 \%$ & $25.4 \%$ & $5.3 \%$ & $6.7 \%$ & $14.2 \%$ & 38 \\
\hline & $\begin{array}{l}\text { Other problems than } \\
\text { C. fusipes (DSF) }\end{array}$ & $33.1 \%$ & $33.3 \%$ & $10.6 \%$ & $10.7 \%$ & $12.3 \%$ & 1523 \\
\hline & European Network & $21.9 \%$ & $29.2 \%$ & $12.5 \%$ & $11.4 \%$ & $25.0 \%$ & $96^{\mathrm{a}}$ \\
\hline
\end{tabular}

\footnotetext{
${ }^{a}$ No information was available on the presence or absence of $C$. fusipes in European Network stands
}

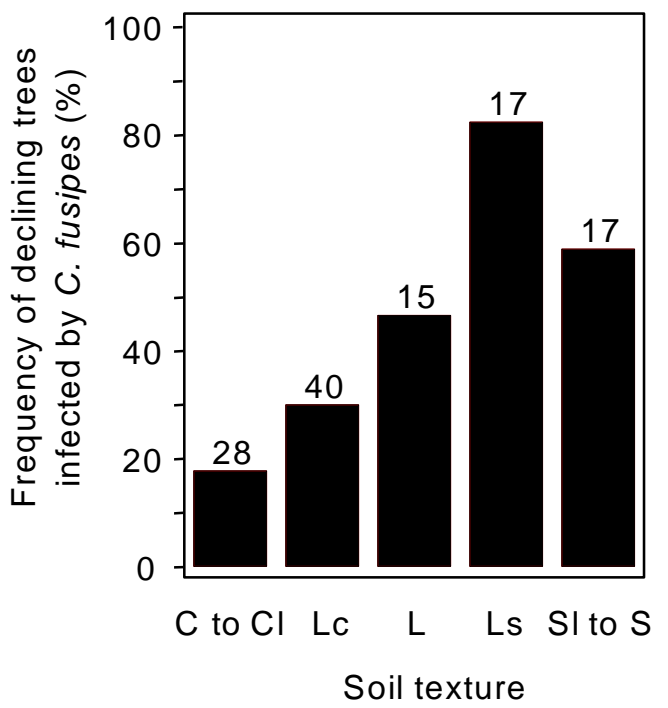

Fig. 1. Frequency of $C$. fusipes DSF database reports associated with oak decline in relation with soil textures. C, clay; Cl, loamy clay; L, Loam; Ls, sandy loam; SI, loamy sand; S, sand. The total number of reports on which the frequency was computed are indicated above the bars 
The frequency of $C$. fusipes reports associated with decline symptoms increased with the coarseness of the soil texture (Fig. 1) $\left(\chi^{2}=22.65\right.$, df $\left.=4, p<0.001\right)$. The relationship was similar for all types of stands (Q. robur, Q. petraea or mixed Q. roburlQ. petraea), so data of all stand types were pooled. The cases of oak decline associated with $C$. fusipes represented $9.3 \%$ of the oak declines reported in the data base. However, if one take into account only decline reports on coarse soils (sandy loam to sandy texture) where $C$. fusipes root rot was shown to be more narrowly associated with decline, they represent $4.5 \%$ of the decline reports over all oak species and $7.4 \%$ of the decline reports on $Q$. robur.

\subsection{Plot survey : influence of soil factors on the relative decline risk for oaks infected with C. fusipes}

On average, $17 \%$ of oaks that showed signs of $C$. fusipes infection were rated as severely declining. However, this percentage varied between 0 and $60 \%$ among plots. By contrast, the average percentage of oaks with no signs of infection that were severely declining was $5 \%$ and varied between 0 and $13 \%$.

The likelihood of decline was significantly influenced by signs of $C$. fusipes infection, soil sand content, $\mathrm{pH}$ and waterlogging depth (Table 3). Cation exchange capacity, carbon/nitrogen ratio or the nature of soil layer limiting rooting did not interact with $C$. fusipes infection ( $i$. e. the interaction 'soil factor x C. fusipes infection' was not significant for these soil characteristics; results not shown). Conversely, the interaction between $C$. fusipes infection and soil factors such as sand content, waterlogging depth or $\mathrm{pH}$ was significant (Table 3). Indeed, Fig. 2 shows that the frequency of declining oaks with signs of $C$. fusipes infection increased with soil sand content, waterlogging depth and decreasing soil $\mathrm{pH}$. These soil characteristics did not influence the decline frequency of oaks showing no signs of C. fusipes infection.

Table 3. Logistic regression analyses showing relationships between oak crown health status (rated as severely declining or healthy to moderately declining) and presence of C. fusipes infection signs, soil sand content, depth to waterlogging signs (traces of oxydized or depleted iron) and soil $\mathrm{pH}$.

\begin{tabular}{cccccc}
\hline Model & Source & Deviance & Df & Chi-Square & Pr $>$ Chi-Square \\
\hline \multirow{2}{*}{$\mathbf{1}$} & intercept & 151.6 & - & - & - \\
& infection & 101.3 & 1 & 50.29 & $<\mathbf{0 . 0 0 1}$ \\
& sand content & 77.4 & 1 & 23.88 & $<\mathbf{0 . 0 0 1}$ \\
& infection X sand content & 70.4 & 1 & 7.02 & $\mathbf{0 . 0 0 8}$ \\
\hline \multirow{2}{*}{$\mathbf{2}$} & intercept & 151.6 & - & - & - \\
& infection & 101.3 & 1 & 50.29 & $<\mathbf{0 . 0 0 1}$ \\
& waterlogging & 94.3 & 1 & 7.01 & 0.008 \\
& infection X waterlogging & 89.8 & 1 & 4.50 & $\mathbf{0 . 0 3 4}$ \\
\hline \multirow{3}{*}{$\mathbf{3}$} & intercept & 151.6 & - & - & - \\
& infection & 101.3 & 1 & 50.29 & $<\mathbf{0 . 0 0 1}$ \\
& pH & 97.2 & 1 & 4.05 & 0.044 \\
& infection X pH & 62.1 & 1 & 5.15 & $\mathbf{0 . 0 2 3}$ \\
\hline
\end{tabular}

There was a strong collinearity between these three soil factors. Significant correlations were observed between soil sand content and the waterlogging depth as well as with soil $\mathrm{pH}$ (Pearson's $r$ of 0.52 and -0.62 respectively, $\mathrm{p}<0.003$ ) while waterlogging depth and soil $\mathrm{pH}$ were not significantly correlated $(r=-0.28, p=0.131)$. Adding the variable 'waterlogging' and the interaction 'infection $x$ waterlogging' to model (1) (Table 3) did not reduce significantly the 
deviance (likelihood Chi-Square of $0.8, \mathrm{p}=0.67$ ). Similarly, adding the variables 'soil $\mathrm{pH}$ ' and the interaction 'infection $\mathrm{x}$ soil $\mathrm{pH}$ ' to this model did not result in a significant drop in deviance (likelihood Chi-Square of 1.6, $\mathrm{p}=0.45$ ).

The estimates of the odds ratio $(\mathrm{OR})$ for the soil sand content, the waterlogging depth or the soil $\mathrm{pH}$ are given by the following equations: $\mathrm{OR}$ (sand) $=\exp (0.57+(0.025 \times$ sand content)) (Wald test for $\delta$ of 6.81, $p=0.009)$; OR(waterlogging $)=\exp (0.69+(0.02 \times$ depth waterlogging)) (Wald test for $\delta$ of $5.17, \mathrm{p}=0.023)$; OR $(\mathrm{pH})=\exp (6.67-(1.13 \times$ soil $\mathrm{pH})$ ) (Wald test for $\delta$ of $4.29, p=0.038$ ). The increase with soil coarseness in relative decline risk for oaks showing signs of $C$. fusipes is illustrated in Figure 3.

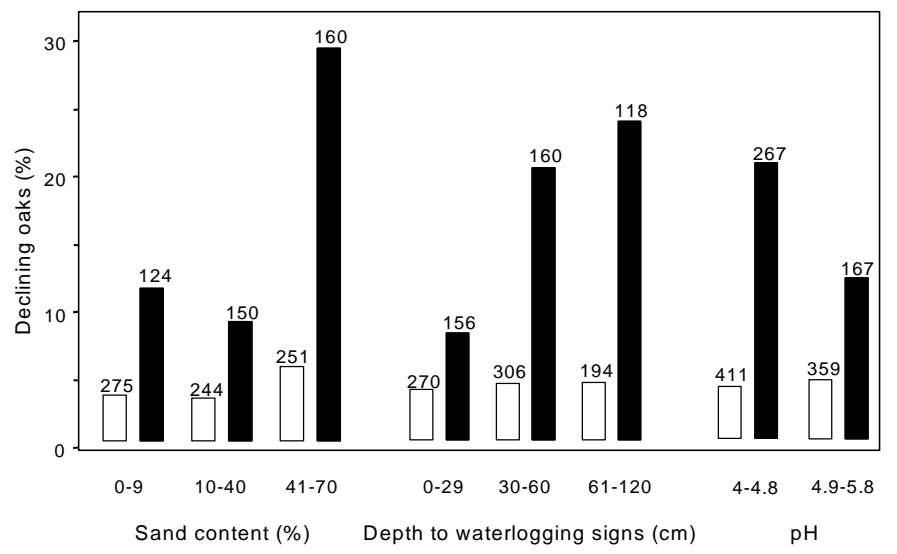

Fig. 2. Percentage of declining pedunculate oaks for different soil sand content, depth to first waterlogging signs (traces of oxydized iron or depleted iron) or $\mathrm{pH}$. Oaks non infected $(\square)$ and infected ( $\square$ ) by $C$. fusipes. Sand content of soil, depth to waterlogging signs and soil $\mathrm{pH}$ have been categorised. The total number of oaks in each category is given above the bars.

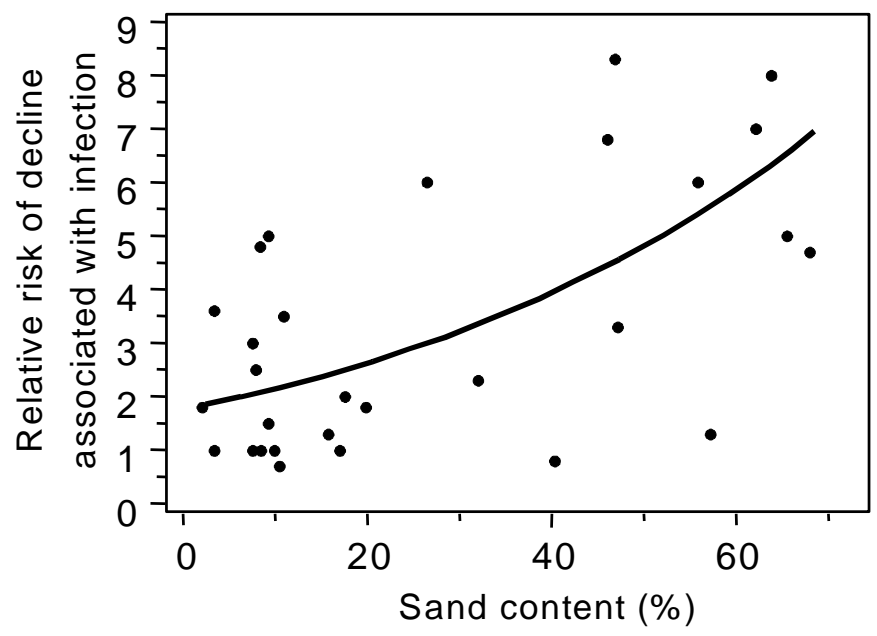

Fig. 3. Estimation of the relative decline risk for pedunculate oaks infected by $C$. fusipes in relation to soil textures. The line represents the odds ratio computed as: $\exp (0.57+0.025 x$ sand content). The fitted logistic model equation was: $\log (p /(1-$ p)) $=-3.17+0.006 x$ sand content $+0.57 x$ infection $+0.025 x$ sand content $x$ infection . To compute the relative risk, whenever no declining tree was present among trees without signs of $C$. fusipes infection, the frequency of decline for non infected was taken as $4 \%$ which represent the mean decline rate of non infected trees for all studied plots. 


\section{Discussion}

Our results clearly show that $C$. fusipes is preferentially distributed in coarse textured soils and that its impact on trees, evaluated through the likelihood of crown decline for infected trees, also increases with the soil sand content.

The DSF database was used to determine the relation between $C$. fusipes incidence and soil textures. Such a comparison is difficult to establish due to the lack of a proper reference. Taking as a reference the problems other than $C$. fusipes reported in the DSF database have the advantage that all site characteristics are readily comparable. However, this reference is potentially biased as it refers to sites with health problems. The European network represents a better view of the French oak forest due to its systematic nature. However, it is very difficult to use as a reference because of the very uneven distribution of DSF trained foresters in France and also because of the fact that site characteristics are not measured exactly in a similar way in each database. However, both comparisons yielded similar results.

These results agree with a previous study which showed that, at the plot scale, the severity of root damages induced by $C$. fusipes on $Q$. robur increased with an increase in soil sand content but decrease with the degree of waterlogging (CAMY et al. 2003-a). Furthermore, our results are in agreement with those of different field surveys concerning other root rot fungi, such as $A$. ostoyae, $\mathrm{H}$. annosum, Inonotus tomentosus or Phellinus noxius. These pathogens appear to have, in sandy soils, a higher incidence (BERNIER and LEWIS 1999; FROELICH et al. 1966; CÔTÉ and DESSUREAULT 1994), a preferential distribution (MC LAUGHLIN 2001; TERMORSHUIZEN and ARNOLDS 1994; CHANG and YANG 1998; BLODGETT and WORRALL 1992) or to induce more damages in terms of root infection severity, rate of decline or mortality (ALEXANDER et al. 1975; WHITNEY 1984; MALLETT and MAYNARD 1998). Inoculation experiments under controlled conditions also showed that the proportion of infected seedlings by Armillaria spp. increased in sandy soils (REDFERN 1978). BAKER et al. (1993) also showed that the risk of lethal root rot on Pinus after inoculation with $H$. annosum increased in soils with low silt, high sand content and low $\mathrm{pH}$.

The fact that coarse soils are favourable to the presence and the impact of $C$. fusipes could result either from a direct effect on the fungus itself or from an effect on the host tree. Indeed, it could be related to the way $C$. fusipes infects trees. Collybia appears to grow along roots mainly through ectotrophic mycelium and to infect bark secondarily (MARÇAIS and DELATOUR 1996). Lesion development is thus strongly subjected to soil conditions. Such an influence of soil conditions on disease evolution have been suggested by RISHBETH (1951) who hypothesised that $H$. annosum incidence decreased in soils rich in organic matter due to the competition with other fungi that are abundant in such soil types. BLENIS et al. (1989) showed a direct and positive effect of sandy texture on $A$. ostoyae through a better survival of inoculum in such soils. Similar results were obtained with $C$. fusipes (CAMY et al. 2003-b). C. fusipes could also be favoured by the good availability in oxygen in sandy textures of soils. Indeed, its growth appeared to be strongly reduced by hypoxia compared to other root rot fungi (CAMY et al. 2003-c). Anoxic conditions induced by waterlogging are very unfavourable to C. fusipes (PIOU et al. 2002, CAMY et al. 2003-C). Another hypothesis was expressed by ALEXANDER et al. (1975) who demonstrated that conidiospores of $H$. annosum could migrate deeper into soils of high sand content, which might also explain the higher disease incidence in those soils. Indeed, deeper migration of inoculum could increase the probability of spores to reach and infect roots. This hypothesis could well fit $C$. fusipes biology as this pathogen spreads essentially by the way of basidiospores (MARÇAIS et al. 1998-b).

However, the difference in distributions of $C$. fusipes reports on $Q$. robur and $Q$. petraea that we evidenced might indicate that soil texture does not only favour the pathogen itself, but may influence the host-pathogen interaction specifically for $Q$. robur. This might suggest an effect of soil coarseness on the tree itself. Such soils are often poor in 
nutrients and prone to water shortage in case of drought. These conditions could weaken the host and increase its susceptibility to $C$. fusipes. This could be especially relevant because Q. robur was often introduced in sites beyond its optimal ecological range, i.e. in soils poor in nutrients and/or with low water holding capacity (BECKER and LÉVY 1990). Nevertheless, C. fusipes is considered to be a primary parasite, since MARÇAIS and DELATOUR (1996) evidenced that young oak seedlings defoliated for two years were less susceptible to C. fusipes infection as compared to not defoliated ones. CAMY (2002) was not able to evidence an increased susceptibility of inoculated saplings of $Q$. robur submitted to drought as compared to well watered controls. Also, artificially inoculated mature $Q$. robur growing on coarse textured soils did show a higher susceptibility to $C$. fusipes compared to oaks growing on fine textured soils (CAMY et al. 2003-b). It could also be possible that infected oaks with root systems severely reduced are more prone to water stress in coarse textured soils with low water holding capacity. This lower tolerance of $Q$. robur to $C$. fusipes infection on coarse textured soil could lead to more frequent reports of the pathogen on these soils.

This study showed that sites where $C$. fusipes could be a cause of oak decline are sites where mature $Q$. robur occur on coarse textured soils. These situations represent $7.4 \%$ of the $Q$. robur declines reported in the DSF database. These soil types are not considered to be within the normal ecological range of $Q$. robur. In coarse textured soils, where $Q$. robur are suffering decline problems due to $C$. fusipes, the replacement of pedunculate oaks by $Q$. rubra should be avoided, since this species is more susceptible to $C$. fusipes (MARÇAIS and CAËL 2000). By contrast, the replacement of pedunculate oaks by $Q$. petraea could be considered in specific situations, since this species is less susceptible to $C$. fusipes and more resistant to water stress and low nutrient availability (BECKER and LÉVY 1990).

\section{Acknowledgements}

The authors wish to thank O. CAËL, F. BERNARD and G. MARECHAL for their technical assistance. The DSF "corespondant observateurs" were of a great help to find enough heavily $C$. fusipes infected stands and we wish to more specially thank P. GRANDJEAN and P.J. BERNARD for this help. We also wish to thank J.P. RENAUD for reviewing the manuscript. The work reported forms part of PhD thesis submitted to the University of Nancy by the first author and was supported by a grant from the 'Institut National de la Recherche Agronomique' and from the 'Région Lorraine'.

\section{Résumé}

Facteurs édaphiques, dépérissement du chêne et infection par Collybia fusipes

Collybia fusipes est à l'origine d'une pourriture racinaire sur chêne en Europe. Les dommages racinaires induits sont corrélés de façon inconstante avec une détérioration de la couronne selon le peuplement. Cette étude a pour but de clarifier les relations entre l'impact de $C$. fusipes sur les chênes, évalué grâce à l'état du houppier, et les facteurs du sol. Pour ceci, la base de données du DSF (Département de la Santé des Forêts Françaises), sur les 12 dernières années, nous a permis d'étudier à large échelle dans quelles textures de sol $C$. fusipes était plus particulièrement liée à des problèmes sanitaires. Une étude plus spécifique, portant sur 30 placettes du nord-est de la France nous a permis de déterminer quels facteurs du sol, texture, degré d'engorgement, présence et nature d'un horizon limitant l'enracinement des arbres, ratio carbone/azote, capacité d'échange cationique ou $\mathrm{pH}$, pouvaient être corrélés à une augmentation du risque de dépérissement chez les chênes infectés par $C$. fusipes. Les résultats ont montré que $C$. fusipes était préférentiellement distribuée sur les sols à textures grossières et que son impact en terme de dépérissement des arbres augmentait avec la teneur en sable du sol. 


\section{References}

AFNOR, 1999, Qualité des sols. Recueil des normes françaises. $4^{\mathrm{e}}$ édition, Paris, La Défense, $996 \mathrm{pp}$.

ALEXANDER, S.A.; Skelly, J.M.; Morris, C.L., 1975: Edaphic factors associated with the incidence and severity of disease caused by Fomes annosus in loblolly pine plantations in Virginia. Phytopathology 65, 585-591.

BAKER, F.A.; VeRBILA, D.L.; HODGES, C.S., 1993: Classification and regression tree analysis for assessing hazard of pine mortality caused by Heterobasidion annosum. Plant Dis. 77, 136139.

BECKER, M.; LeVY, G., 1990: Le point sur l'écologie comparée du chêne sessile et du chêne pédonculé. Rev. For. Fr. 42, 148-154.

BERNIER, D.; LEWIS, K.J., 1999: Site and soil characteristics related to the incidence of Inonotus tomentosus. For. Ecol. Manage. 120, 131-142.

BLEnIS, P.V.; MulaGa, M.S.; HiRATSUKA, Y., 1989: Soil affects Armillaria root rot of lodgepole pine. Can. J. For. Res. 19, 1638-1641.

BLodgetT, J.T.; WORRALL, J.J., 1992: Site Relationships of Armillaria Species in New York. Plant Dis. 76, $170-174$.

BULLER, H.A.R., 1958: The perennial pseudorhiza of Collybia fusipes, In: Researches on Fungi. Vol. VI. New York Hafner Publishing CO, pp. 374-396.

CAMY, C. 2002. Influence des facteurs édaphiques et sylvicoles sur le développement du pourridié à Collybie (Collybia fusipes) dans la chênaie pédonculée. PhD of University of Nancy I, 88 p.

Camy, C.; Delatour, C.; MarÇAIS, B., 2003-a Relationships between soil factors, Quercus robur health, Collybia fusipes root infection and Phytophthora presence. Ann. For. Sci. 60: 419426.

Camy, C.; Delatour, C.; Cä̈l O.; MarÇAis B., 2003-b Inoculation of mature pedunculate oaks (Quercus robur) with the root rot fungus Collybia fusipes: relationships with tree vigour and soil factors. Eur. J. Plant. Pathol. 109: 545-553.

Camy, C.; Dreyer, E.; Delatour, C.; MarÇais, B., 2003-c Responses of the root rot fungus Collybia fusipes to soil waterlogging and oxygen availability. Mycol. Res. 107: 1103-1109.

Chang, T.T.; YANG, W.W., 1998: Phellinus noxius in Taiwan: distribution, host plants and the pH and texture of the rhizosphere soils of infected oaks. Mycol. Res. 102, 1085-1088.

Collett, D., 1991: MOdeling Binary Data. London UK, CHAPMAN and HALL, 369 pp.

CÔTÉ, E.; DessuREAULT, M., 1994: Effects of site factors on the occurrence of Armillaria root rot disease in black spruce (Picea mariana mill.(B.S.P.) ) seed orchards., In: Proc 8th Int. Conf. Root and Butt Rots, Wick, Sweden and Haikko, Finland. August, 9-16, 1993. Ed. by JOHANSSON, M; STENLID, J. Uppsala: Swed. Univ. Agri. Sci.(Sweden) pp. 592-596.

Delatour, C.; GuIllaumin, J.J., 1984: Un pourridié méconnu : Collybia fusipes (Bull. ex Fr.) Quel. C. R. Acad. Agri. France 70, 123-126.

Froelich, R.C.; Dell, T.R.; WalkINSHAW, C.H., 1966: Soil factors associated with Fomes annosus in the Gulf States. For. Sci. 12, 356-361.

Guillaumin, J.J.; Bernard, C.; Delatour, C.; Belgrand, M., 1985: Contribution à l'étude du dépérissement du chêne : pathologie racinaire en forêt de Tronçais. Ann. Sci. For. 42, 1-22.

MALLETT, K.I.; MAYNARD, D.G., 1998: Armillaria root disease, stand characteristics, and soil properties in young lodgepole pine. For. Ecol. Manage. 105, 37-44.

MarÇAIS, B.; Delatour, C., 1996: Inoculation of oak (Quercus robur and Q. rubra) with Collybia fusipes. Plant Dis. 80, 1391-1394.

MARÇAIS, B.; CAËL, O., 2000: Comparison of the susceptibility of Quercus petraea, Q. robur and Q. rubra to Collybia fusipes. Eur. J. Plant. Pathol. 106, 227-232.

MARÇAIS, B.; CAËL, O., 2001: Relation between Collybia fusipes root rot and growth of pedunculate oak. Can. J. For. Res. 31, 757-764.

MARÇAIS, B.; CAËL, O.; DelATOUR, C., 1998-a: Investigations on the distribution and impact of Collybia fusipes in Oak forest, In: Proc $9^{\text {th }}$ Int. Conf. Root and Butt Rots, Carcans-Maubuisson, France September, 1-7, 1997. Ed. by DeLATOUR C.; GUILLAUMIN J.J., LUNG-ESCARMENT B.; MARÇAIS B. INRA Editions (France), Les Colloques №. 89, pp. 215-222. 
Marçais, B, Martin, F., Delatour, C., 1998-b: Structure of Collybia fusipes populations in two infected oak stands. Mycol. Res. 102, 361-367.

MARÇAIS, B.; CAËL, O.; Delatour, C., 1999: Measuring the impact of Collybia fusipes on the root system of oak trees. Ann. For. Sci. 56, 227-235.

MarÇals, B.; CAËL, O.; Delatour, C., 2000: Relationship between presence of basidiomes, aboveground symptoms and root infection by Collybia fusipes in Oaks. For. Path. 30, 7-17.

MCLAUGHLIN, J.A., 2001: Distribution, hosts, and site relationships of Armillaria spp. in central and southern Ontario. Can. J. For. Res. 31, 1481-1490.

NAGELEISEN L.M., 1995: Méthode d'évaluation de l'aspect du houppier (protocole DePEFEU). Département Santé des Forêts-Echelon technique Nord-Est. Bulletin technique. 11pp.

Piou, D.; Delatour, C.; Marçais, B., 2002: Hosts and distribution of Collybia fusipes in France. For. Path. 32, 29-41

REDFERN D.B., 1978: Infection by Armillaria mellea and some factors affecting host resistance and the severity of disease. Forestry $\mathbf{5 1 , 1 2 1 - 1 3 5 .}$

RISHBETH J., 1951: Observations on the biology of Fomes annosus, with particular references to east anglian plantations. III / Natural and experimental infection of pines, and some factors affecting severity of the disease. Annals of Botany 15, 221-247.

SAS, 1989: SAS/STAT User's Guide, Version 6, Fourth edition, Vol. I Cary, NC: SAS Institute Inc. 943 $\mathrm{pp}$.

TeRmORSHUIZEN, A.J.; ARNOLDS, J.M., 1994: Geographical distribution of the Armillaria species in the Netherlands in relation to soil type and hosts. Eur. J. For. Path. 24, 129-136.

WHITNEY, R.D., 1984: Site variation of Armillaria mellea in three Ontario conifers, In: Proc $6^{\text {th }}$ Int. Conf. Root and Butt Rots, Melbourne, Victoria, Gympie, Queensland, Australia; August, 25-31, 1983. Ed by KILE, G.A. CSIRO Melbourne (Australia)pp. 122-130.

WIENSCYK, A.M.; DUMAS, M.T.; IRWIN, R.N., 1997: Predicting Armillaria ostoyae infection levels in black spruce plantations as a function of environmental factors. Can. J. For. Res. 27, 1630-1634. 